\title{
Management of Seed-Borne Fungi in Cowpea Using Leaf Extracts and Sodium Bicarbonate
}

\section{1*KAREEM, KT; ${ }^{2}$ AFOLABI, QO; ${ }^{2}$ SHORINMADE, AY; ${ }^{3} \mathrm{AKINBODE,} \mathrm{OA}$}

\author{
${ }^{l}$ Grain Legumes Improvement Programme, Institute of Agricultural Research and Training, Obafemi Awolowo University, Ibadan \\ ${ }^{2}$ Department of Science Laboratory Technology, Federal College of Animal Health and Production, Ibadan \\ ${ }^{3}$ Maize Improvement Programme for Southern Ecologies, Institute of Agricultural Research and Training, Obafemi Awolowo University, \\ Ibadan \\ "Corresponding AuthorE-mail: kt_kareem@yahoo.com; Phone: 08024158641
}

\begin{abstract}
The study investigated the in-vitro antifungal activities of sodium bicarbonate $\left(\mathrm{NaHCO}_{3}\right)$ and leaf extracts of Vernonia amydgalina (bitter leaf) and Azadirachta indica (neem) on fungal species isolated from two cowpea cultivars; IFE BROWN and Drum (a local cultivar). Concentrations of $1.95 \mathrm{mg} / \mathrm{ml}$ and $1.43 \mathrm{mg} / \mathrm{ml}$ were used for A. indica while $1.45 \mathrm{mg} / \mathrm{ml}$ and $1.15 \mathrm{mg} / \mathrm{ml}$ were used for V. amydgalina. Sodium bicarbonate was evaluated on all the isolates at $2.0 \mathrm{mg} / \mathrm{ml}$ and $3.0 \mathrm{mg} / \mathrm{ml}$. The inhibitory effects of these antifungal agents were compared with benlate (a synthetic fungicide) on Potato Dextrose Agar. Benlate totally inhibited all the fungal isolates. Candida species isolated from the two cowpea cultivars were greatly inhibited by the antifungal agents while Trichoderma species isolated from IFE BROWN was the least inhibited. The inhibitory effects of $\mathrm{NaHCO}_{3}$ and A. indica on Candida spp. were not significantly different and values ranged from $74.5 \%$ to $84 \%$. The two concentrations of $A$. indica had better inhibitory effect on Pythium spp. than $\mathrm{NaHCO}_{3}$. Vernonia amydgalina at $1.45 \mathrm{mg} / \mathrm{ml}$ inhibited A. niger and Candida spp. by $83.75 \%$ and $87.5 \%$ respectively while $\mathrm{NaHCO}_{3}$ at $2.0 \mathrm{mg} / \mathrm{ml}$ inhibited Rhizopus stolonifer isolated from Drum by $75 \%$. The study concludes that the two plant extracts and sodium bicarbonate had broad spectrum activities on fungal species and are therefore recommended as alternatives to toxic and synthetic fungicides.
\end{abstract}

DOI: https://dx.doi.org/10.4314/jasem.v22i4.23

Copyright: Copyright (C) 2018 Kareem et al. This is an open access article distributed under the Creative Commons Attribution License (CCL), which permits unrestricted use, distribution, and reproduction in any medium, provided the original work is properly cited.

Dates: Received: 08 March; Revised: 15 April: 2018; Accepted: 21 April 2018

Key words: Cowpea, eco-friendly, fungicide, inhibition

Cowpea (Vigna unguiculata L. Walp.) is regarded as the most essential legume crop for poor people in developing countries (Valenzuela and Smith, 2002; Langyintuo et al., 2003). It is a major source of indigenous plant protein in Nigeria (Ndem and Sowemimo, 2004) and $40 \%$ of the people daily protein requirements is supplied by cowpea (Muleba et al., 1997; Egho, 2009). Some important local names of cowpea include "niebe","wake"and "ewa" other common names of cowpea are "southern pea", "black eye pea", "field pea", "pink eyes" and "crowder" (Singh et al., 2002). The production and storage of cowpea are hindered by an array of pests and diseases which affect yield, quality, nutritional value and viability. Lack of adequate storage and transport facilities have led to severe postharvest losses experienced in developing countries (Sharma et al., 2009), thus, making the environment more conducive for the growth of storage fungi. Furthermore, most of these fungi produce toxic metabolites, called mycotoxins, which constitute health problems to humans, animals and plants (Reverberi et al., 2010).
Various synthetic fungicides used on cowpea have some adverse effects such as toxic residue, development of resistant strain, high cost and toxicity to mammals because some of them contain heavy metals (Azher, 2009). Hence, there is need for ecofriendly alternatives to seed dressing chemical fungicide in the control of seed-borne fungi. Such alternatives include the use of organic materials such as plant extracts and inorganic salts such as sodium bicarbonate. Plant materials are safe for use in the environment and are inexpensive. Therefore, they can be exploited as suitable alternatives to the expensive, toxic and environmentally unsafe synthetic fungicides (Isman, 2006; Akunne et al., 2013). The leaf of neem (Azadirachta indica) and its constituents have been reported to exhibit immunomodulatory, antiinflammatory, antihyperglycaemic, antiulcer, antimalaria, antifungal, antibacterial, antioxidant, antimutagenic and anticarcinogenic properties (Subapriya and Nagini, 2005). The aqueous extract of neem has powerful chemotherapeutic and antiviral activities (Hassan et al., 2010). The seed extract of neem was reported to retard the growth of two fungi; 
Gaeumannomyces graminis and Typhula inccarnata (Coventry and Allan, 2001).

Vernonia amygdalina, a member of the Asteraceae family has been used traditionally to treat sexually transmitted diseases such as gonorrhea and malaria in rift valley and western parts of Kenya (Erasto et al., 2007). The multiple health benefits of Vernonia amygdalina include anticancer (Sweeney et al., 2005), anti-diabetic (Nwanjo, 2005), antioxidant (Erasto et al., 2007) amongst others. The aqueous extract of this plant has been found to have cell growth inhibitory effects in prostate cancer cell line (Adebayo et al., 2014). The leaves and the roots are used traditionally in phytomedicine to treat fever, kidney, heart diseases and stomach discomfort (Farombi and Owoeye, 2011).

There is a growing interest in the use of sodium bicarbonate $\left(\mathrm{NaHCO}_{3}\right)$ and potassium bicarbonate $\left(\mathrm{KHCO}_{3}\right)$ for the control of numerous fungal diseases in plants (Karabulut et al., 2003; Smilanick et al., 2006). Bicarbonates are widely used in the food industry (Lindsay, 1985), and therefore, have no negative effect on the environment, plants or humans. Ziv and Zitter (1992) reported the ability of bicarbonates to suppress several fungal diseases of cucumber plants. Spraying plants with $\mathrm{NaHCO}_{3}$ solution provided good control of several plant diseases (Janisiewicz and Peterson, 2005). Therefore, this study evaluated the inhibitory effects of the leaf extracts of two plants (Azadirachta indica and Vernonia amygdalina) and an inorganic salt; sodium bicarbonate on fungal species isolated from cowpea seeds.

\section{MATERIALS AND METHODS}

Two varieties of cowpea namely IFE BROWN and Drum were used in this study. IFE BROWN was obtained from the Institute of Agricultural Research and Training, Obafemi Awolowo University, Ibadan while Drum (a local cultivar) was obtained from Apata market, Ibadan, Nigeria. Seeds were surfaced sterilized according to the method of Mohammadi and Sivritepe (2007) with modifications using 70\% ethanol for $1 \mathrm{~min}$ and later $10 \%$ hypochlorite solution for 30 mins. Then the seeds were rinsed in five changes of distilled water and dried on sterilized paper towel. Seed-borne fungal pathogens were isolated from cowpea seeds on Potato Dextrose Agar (PDA) using Agar plate method as described by Anon (1993). The isolated fungi were identified using cultural appearance and microscopic characteristics (Ogbulie et al., 2001).

Leaves of Azadirachta indica and Vernonia amygdalina were collected from the whole plants, washed in distilled water and air dried between 7 to10 days. The leaves were ground into powder using a kitchen blender. Approximately $40 \mathrm{~g}$ and $50 \mathrm{~g}$ of the pulverized leaves were soaked in $100 \mathrm{ml}$ of distilled water overnight. After soaking, the mixture was sieved into a $250 \mathrm{ml}$ conical flask using a sterile muslin cloth. The plant residues were dried, weighed and subtracted from the initial weights of the pulverized leaves to obtain the actual concentrations of plant extracts. Concentrations of $1.95 \mathrm{mg} / \mathrm{ml}$ and $1.43 \mathrm{mg} / \mathrm{ml}$ were obtained from Azadirachta indica at $40 \mathrm{~g}$ and $50 \mathrm{~g}$ of leaves respectively while $1.45 \mathrm{mg} / \mathrm{ml}$ and $1.15 \mathrm{mg} / \mathrm{ml}$ were obtained from $40 \mathrm{~g}$ and $50 \mathrm{~g}$ of Vernonia amygdalina leaves respectively.

Frequency of occurrence of isolated fungi: The frequency of occurrence of the isolated fungi was determined by counting the number of times each fungal species appeared in the mixed culture. Percent occurrence of each of the fungal species was calculated as shown below:

$P C=\frac{F F I \times 100}{T F I}$

Where PC $=\%$ occurrence; FFI $=$ frequency of occurrence of each fungal isolate; TFI $=$ total occurrence of all fungal isolates

Evaluation of the efficacies of plant extracts and sodium bicarbonate against fungal isolates: The inhibitory effects of the leaf extracts of Azadirachta indica at $1.95 \mathrm{mg} / \mathrm{ml}$ and $1.43 \mathrm{mg} / \mathrm{ml}$ were tested against fungal species isolated from IFE BROWN variety while Vernonia amygdalina at $1.45 \mathrm{mg} / \mathrm{ml}$ and $1.15 \mathrm{mg} / \mathrm{ml}$ were tested on the fungal species isolated from Drum. Similarly, sodium bicarbonate was evaluated on all the isolates at $2.0 \mathrm{mg} / \mathrm{ml}$ and $3.0 \mathrm{mg} / \mathrm{ml}$. Benlate (a.i 50\% Benomyl); a synthetic fungicide was also tested on the fungal isolates. Approximately $1.0 \mathrm{ml}$ of each antifungal agent was dispensed into $90 \mathrm{~mm}$ diameter Petri dishes using sterile syringe. Sterilized molten PDA was dispensed into the Petri dishes and swirled to allow even distribution of the antifungal agents. Agar was allowed to solidify and each plate was inoculated with actively growing margin of fungal colonies using a sterilized 5 $\mathrm{mm}$ diameter cork borer. There were three replicates and plates were incubated at room temperature with radial mycelia growth measured daily until the control treatment (plate without antifungal agent) was fully covered with the mycelia. The mycelia growth was determine using the formula adopted from Oyedeji and Kareem (2016).

$$
M p=\frac{\mathrm{M} 1-M 2 \times 100}{M 1}
$$


Where: $\mathrm{Mp}=$ Percentage inhibition of mycelia growth; M1= Mycelia growth in control plate; M2= Mycelia growth in treated plate.

Statistical analysis: Data obtained were subjected to statistical analysis using Statistical package for social sciences (SPSS) and means were compared using Duncan Multiple Range test at 5\% level of probability.

\section{RESULTS AND DISCUSSION}

Frequency of occurrence of isolated fungi: Four fungal species were isolated from the seeds of IFE BROWN and they include Candida spp, Pythium spp., Rhizopus stolonifer and Trichoderma spp. The frequency of occurrence of all the isolated fungi was not significantly different from each other. The occurrence frequency of Pythium spp., Candida spp. and Trichoderma spp. was 3.0 while that of Rhizopus stolonifer was 4.5 (Table 1). This corroborates the research of Makun et al. (2012) which reported the incidence of seed-borne fungi in cowpea survey carried out in Niger State, Nigeria.

Rhizopus stolonifer, Aspergillus niger, and Candida spp. were the fungal species isolated from the local cultivar; Drum. Results revealed that Aspergillus niger and Rhizopus stolonifer had frequency of occurrence of 1.5 while Candida spp. had a frequency of occurrence of 1.0. The percent occurrence of Candida spp. was $25.0 \%$ while Aspergillus niger and Rhizopus stolonifer had percent occurrence of $37.5 \%$ (Table 1). The occurrences of seed-borne fungi in cowpea have been reported by several authors with Aspergillus spp. being reported as the most frequently occurred (Popoola et al., 2003; Makun et al., 2012; Shahnaz et al., 2015).
Inhibition of fungi by leaf extracts and sodium bicarbonate: The highest inhibited organism by the antifungal agents was Candida spp. isolated from Drum and IFE BROWN at $80.25 \% \pm 5.1$ and $83.5 \% \pm$ 2.9 respectively. This was followed by Aspergillus niger $(79.01 \% \pm 5.2)$ isolated from Drum while the least inhibited organism was Trichoderma spp. (57.5\% \pm 7.2 ) isolated from IFE BROWN (Table 2). Fallik et al. (1997) reported that the inhibitory effect of sodium bicarbonate on microorganisms could be due to the reduction of cell tugor which causes collapse and shrinkage of hyphae and spores resulting in fungistasis. The fungicidal properties of aqueous extract of $V$. amydgalina against Fusarium in-vitro was reported by Suleiman et al. (2008). Fungal growths were totally inhibited by benlate while $A$. indica and sodium bicarbonate at different concentrations also inhibited the growth of the fungi isolated from IFE BROWN but not as much as benlate. This result is not surprising because benlate is a synthetic fungicide and its effect on microorganisms is highly toxic. The inhibition of $B$. theobromae by three synthetic fungicides has been reported by Oyedeji and Kareem (2016).

There was no significant difference in the activity of sodium bicarbonate and $A$. indica on Candida spp. However, A. indica at $1.95 \mathrm{mg} / \mathrm{ml}$ and $1.43 \mathrm{mg} / \mathrm{ml}$ controlled Pythium spp. better than sodium bicarbonate at the two concentrations. Rhizopus stolonifer was inhibited by $70 \%$ and $67.75 \%$ at 1.95 $\mathrm{mg} / \mathrm{ml}$ of $A$. indica and $3.0 \mathrm{mg} / \mathrm{ml}$ of sodium bicarbonate respectively. The highest inhibition (53\%) of Trichoderma spp. was by $2.0 \mathrm{mg} / \mathrm{ml}$ of sodium bicarbonate (Table 3).

Table 1: Occurrence of fungi isolated from the seeds of IFE BROWN and Drum

\begin{tabular}{lllll}
\hline & \multicolumn{2}{c}{ IFE BROWN } & \multicolumn{2}{c}{ Drum } \\
\hline Pathogen & Frequency of occurrence & $\%$ occurrence & Frequency of occurrence & $\%$ occurrence \\
\hline Candida spp. & $3.0^{\mathrm{a}}$ & $22.22^{\mathrm{a}}$ & $1.5^{\mathrm{a}}$ & $37.5^{\mathrm{a}}$ \\
Pythium & $3.0^{\mathrm{a}}$ & $22.22^{\mathrm{a}}$ & $\mathrm{NI}$ & $\mathrm{NI}$ \\
Rhizopus & $4.5^{\mathrm{a}}$ & $33.33^{\mathrm{a}}$ & $1.5^{\mathrm{a}}$ & $37.5^{\mathrm{a}}$ \\
Trichoderma & $3.0^{\mathrm{a}}$ & $22.22^{\mathrm{a}}$ & $\mathrm{NI}$ & $\mathrm{NI}$ \\
Aspergillus niger & $\mathrm{NI}$ & $\mathrm{NI}$ & $1.0^{\mathrm{a}}$ & $25.0^{\mathrm{a}}$ \\
\hline
\end{tabular}

Means followed by the same letter along the columns are not significantly different according to Duncan's Multiple Range Test (DMRT). $N I=$ not isolated

Table 2. Descriptive statistics of antifungal agents on fungal isolates

\begin{tabular}{lllll}
\multicolumn{5}{c}{ Table 2. Descriptive statistics of antifungal agents on fungal isolates } \\
\hline Variety & Fungal species & Mean & S.E & Range \\
\hline Drum & Aspergillus niger & 79.01 & 4.0 & 33.75 \\
& Rhizopus stolonifer & 73.99 & 5.2 & 56.30 \\
& Candida species & 80.25 & 5.1 & 56.25 \\
\hline IFE BROWN & Candida species & 83.50 & 2.9 & 25.50 \\
& Phythium & 70.50 & 6.3 & 50.50 \\
& Rhizopus stolonifer & 69.95 & 5.6 & 53.00 \\
& Trichoderma species & 57.50 & 7.2 & 59.00 \\
\hline
\end{tabular}

S.E $=$ standard error 
Table 3. Percentage inhibition induced by Azadiracta indica and sodium bicarbonate on fungi isolated from IFE BROWN

\begin{tabular}{cllll}
\hline $\begin{array}{l}\text { Concentration of antifungal } \\
\text { agents }(\mathrm{mg} / \mathrm{ml})\end{array}$ & Candida $\mathrm{spp}$. & $\begin{array}{l}\text { Pythium } \\
\text { spp. }\end{array}$ & $\begin{array}{l}\text { Rhizopus } \\
\text { stolonifer }\end{array}$ & $\begin{array}{l}\text { Trichoderma } \\
\text { spp. }\end{array}$ \\
\hline $1.95($ A. indica $)$ & $84.0 \mathrm{~b}$ & $78.0 \mathrm{~b}$ & $70.0 \mathrm{~b}$ & $47.0 \mathrm{bc}$ \\
$1.43($ A. indica) & $79.0 \mathrm{~b}$ & $75.0 \mathrm{~b}$ & $65.0 \mathrm{bc}$ & $40.5 \mathrm{c}$ \\
$2.0($ NaHCO3) & $74.5 \mathrm{~b}$ & $50.0 \mathrm{c}$ & $47.0 \mathrm{c}$ & $53.0 \mathrm{~b}$ \\
$3.0($ NaHCO3) & $80.0 \mathrm{~b}$ & $49.5 \mathrm{c}$ & $67.75 \mathrm{~b}$ & $47.0 \mathrm{bc}$ \\
1.0 (Benlate) & $100.0 \mathrm{a}$ & $100.0 \mathrm{a}$ & $100.0 \mathrm{a}$ & $100.0 \mathrm{a}$ \\
\hline
\end{tabular}

Means followed by the same letter along the columns are not significantly different according to Duncan's Multiple Range Test (DMRT).

Table 4. Percentage inhibition induced by Vernonia amydgalina and sodium bicarbonate on fungi isolated from Drum

\begin{tabular}{llll}
$\begin{array}{l}\text { Concentration of antifungal } \\
\text { agents }(\mathrm{mg} / \mathrm{ml})\end{array}$ & Aspergillus niger & Candida spp. & Rhizopus stolonifer \\
\hline 1.45 (V.amydgalina $)$ & $83.75 \mathrm{~b}$ & $87.5 \mathrm{ab}$ & $72.5 \mathrm{~b}$ \\
1.15 (V.amydgalina $)$ & $66.25 \mathrm{~d}$ & $80.0 \mathrm{abc}$ & $66.25 \mathrm{~b}$ \\
2.0 (NaHCO3) & $71.28 \mathrm{~cd}$ & $74.38 \mathrm{bc}$ & $75.0 \mathrm{~b}$ \\
3.0 (NaHCO3) & $73.75 \mathrm{c}$ & $59.38 \mathrm{c}$ & $56.22 \mathrm{~b}$ \\
1.0 (Benlate) & $100.0 \mathrm{a}$ & $100.0 \mathrm{a}$ & $100.0 \mathrm{a}$ \\
\hline
\end{tabular}

Means followed by the same letter along the columns are not significantly different according to Duncan's Multiple Range Test (DMRT).

The fungitoxic activity of water and alcoholic extracts of $A$. indica against the causal organism of rice blast has been reported by Amadioha (1999) while Nigro et al. (2006) obtained positive results in the control of $B$. cinerea on table grapes, using calcium chloride, sodium bicarbonate and other carbonate salts. In the local cultivar; Drum; Aspergillus niger was best inhibited $(83.75 \%)$ by $V$. Amygdalina at $1.45 \mathrm{mg} / \mathrm{ml}$ followed by its inhibition $(73.75 \%)$ at $3.0 \mathrm{mg} / \mathrm{ml}$ of $\mathrm{NaHCO}_{3}$. Sodium bicarbonate inhibited Candida spp. by $74.38 \%$ and $59.38 \%$ at 2.0 and $3.0 \mathrm{mg} / \mathrm{ml}$ respectively (Table 4). The inhibition of fungal isolates by sodium bicarbonate and extracts of $A$. indica suggests that both antifungal agents have broad spectrum activities. The result agrees with the earlier study of Karabulut et al. (2003) which reported that sodium bicarbonate effectively controlled postharvest diseases of grapes. In addition, the efficacy of $V$. amydgalina amongst other plant extracts against seedborne fungi isolated from African yam bean was reported by Nwachukwu and Umechuruba (2001).

Conclusion: The presence of seed-borne fungi was evident in this study. Although, the synthetic fungicide used was able to inhibit the growth of the organisms completely but its use by farmers cannot be recommended because of the adverse effects on human health and the environment. The use of sodium bicarbonate and leaf extracts of A. indica and Vernonia amydgalina obviously inhibited the growth of the pathogens and are therefore, recommended for sustainable food production and food security.

Acknowledgement: The authors wish to thank Mr. G.G. Adebayo and Mrs. V. Akin-Ajayi from the Pathology Laboratory of the Institute of Agricultural Research and Training, Ibadan for the technical assistance rendered.

\section{REFERENCES}

Adebayo, OL; Abugri, J; Sumabe, BK; Onilimor, PJ (2014). Leaf extract of Vernonia amygdalina Del. From Northern Ghana contain bioactive agents that inhibit the growth of some Betalactamase producing bacteria in-vitro. Brit. J. Pharm. Res. 4(2):192-202.

Amadioha, AC (1999). Controlling rice blast in-vitro and in-vivo with extracts of Azadirachta indica. Crop Prot. 19:287-290.

Akunne, CE; Ononye, BU; Mogbo, TC (2013). Evaluation of the efficacy of mixed leaf powders of Vernonia amygdalina (L.) and Azadirachta indica (A. Juss) against Callosobruchus maculatus (F.) (Coleoptera: Bruchidae). $A d v$. Biosci. Bioeng. 1(2) 86-95.

Anonymous (1993). International rules for seed health testing. Seed Sci. and Technol. 21:1-288.

Azher, M (2009). Seed Mycoflora of Shisham and their integrated management. Ph.D. Thesis, Department of Plant Pathology. University of Agriculture, Faisalabad, Pakistan. pp. 71-72.

Conventry, E; Allan, EJ (2001). Microbiological and chemical analysis of neem (Azadirachta

indica) extracts. Phytoparasit. 19(50):111-120.

Egho, EO (2009). Control of major insect pests of cowpea (Vigna unguiculata) walp. Using conventional and non-conventional chemicals. A Ph.D. thesis submitted to the Department of Agronomy, Delta State University, Asaba Campus. p.224. 
Erasto, P; Greisen, DS; Afolayan, AJ (2007). Evaluation of antioxidant activity and the fatty acid profile of the leaves of Vernonia amygdalina growing in South Africa. Food Chem. 104:636-642.

Fallik, E; Grinberg, S; Ziv, O (1997). Potassium bicarbonate reduces postharvest decay development on bell pepper fruits. J. of Hort. Sci. 72:35-41.

Farombi, EO; Owoeye, O (2011). Antioxidative and chemopreventive properties of Vernonia amygdalina and Garcinia biflavonoid. Int. J. Environ. Res. in Pub. Health. 8(6):2533-2555.

Hassan, A; Wafaa, A; Helmy, H; Taie, AA (2010). Invitro antitumour activities of seeds and leaves of neem (Azadirachta indica) extracts. Int. J. Acad. Res. 22:165-171.

Isman, MB (2006). Botanical insecticides, deterrents and repellents in modern agriculture and an increasingly regulated world. Ann. Rev. Entomol. 51:45-66.

Janisiewicz, WJ; Peterson, DL (2005). Experimental Bin drenching system for testing biocontrol agents to control postharvest decay of apples. Plant Dis. 89:487-490.

Karabulut, OA; Smilanick, JL; Milkota Gabler, F; Mansour, M; Droby, S (2003). Near-harvest applications of Metschnikowia fructicola, ethanol and sodium bicarbonate to control postharvest diseases of grape in central California. Plant Dis. 87:1384-1389.

Langyintuo, AS; Ntoukan, G; Murdock, L; Lowenberg, D; Deboer, DJ; Faye, MD (2003). Cowpea supply and demand in west and central Africa. Field Crops Res. 82:215-231.

Lindsay, RC (1985). Food additives. In: Food Chemistry. (Fennema, OR. and Dekker, M. eds.). Chapter 10, Inc. New York, USA. pp.664665.

Makun, HA; Anjorin, ST; Abidoye, AS; Rufai, AR; Kabiru, YA (2012). Incidence and botanical control of seed-born fungi of cowpea in Niger State, Nigeria ARPN J. Agric. and Biol. Sci. 7(8):654-658.
Mohammadi, J; Sivritepe, N (2007). In-vitro clonal propagation of Cucumis sativus L. by shoot tip culture. J. Biol. Sci. 7(4):653-657.

Muleba, NC; Dabire, JBS; Drabo, I; Ouedraogo, JT (1997). Technologies for cowpea production based on genetic and environmental manipulations in the semi-arid tropic. In: Technologies Options for Sustainable Agriculture in Sub-Saharan Africa, Bezuneh, T., Emechebe, A.M., Sedgo, J. and Oeudrago, M. Eds., Semi-Arid Food Grain Research and Development Agency (SAFGRAD) of the Scientific, Technical and Research Commission of OAU, Ouagadougou, Burkina Faso. pp. 192206.

Ndem, NUA; Sowemimo, FA (Eds.) (2004). Major legumes and oil seeds of Nigeria: Principles of Production and Utilization. iii pp.66-95.

Nigro, F; Schena, L; Ligorio, A; Pentimone, I; Ippolito, A; Salemo, MG (2006). Control of table grape storage rots by pre-harvest applications of salts. Postharv. Biol. Technol. 42:142-149.

Nwachukwu, EO; Umechuruba, CI (2001). Antifungal activities of some leaf extracts on seed-borne fungi of African yam bean seeds, seed germination and seedling emergence. J. Appl. Sci. and Environ. Manag. 5(1):29-32.

Nwanjo, HU (2005). Efficacy of aqueous leaf extract of Vernonia amygdalina on plasma lipoprotein and oxidative status in diabetic rat models. Nig. J. Physiol. Sci. 20(1-2): 30-42.

Ogbulie, JN; Uwaezuoke, JC; Ogiebor, SI (2001). Introductory Microbiology Practical. $2^{\text {nd }}$ Ed. Concave Publishers, Nigeria. pp. 95-113.

Oyedeji, EO; Kareem, KT (2016). In-vitro evaluation of some fungicides against Botrydiplodia theobroma: Causal pathogen of pineapple dieback. Am. J. Exp. Agric. 11(5):1-7.

Popoola, AR; Adeoti, AYA; Idakwo, PY (2003). Incidence of moulds in some varieties of stored cowpea and peanuts in Maiduguri, Nigeria. Ass. Series A 3(4):163-169.

Reverberi, M; Ricelli, A; Zjalic, S; Fabbri, AA; Fanelli, C (2010). Natural functions of mycotoxins and control of their biosynthesis in fungi. Appl. Microbiol. Biotechnol.87:899-911. 
Shahnaz, D; Maimona, K; Summiaya, R (2015). Seed borne fungi associated with cowpea (Vigna unguiculata (L.) Walp. Int. J. Biol. and Biotechnol. 12(4): 565-569.

Sharma, RR; Singh, D; Singh, R (2009). Biological control of postharvest diseases of fruits and vegetables by microbial antagonists: A review. Bio. Control 50(3): 205-221.

Singh, BB; Chambliss, OL; Sharma, B (2002). Advance in Cowpea Research, Ibadan, Nigeria: International Institute of Tropical Agriculture and Japan International Research Center

for Agricultural Science.

Smilanick, JL; Mansour, MF; Sorenson, D (2006). Pre- and Post-harvest treatments to control green mould of citrus fruit during ethylene degreasing. Plant Dis. 90:89-96.

Subapriya, R; Nagini, S (2005). Medicinal properties of neem leaves: A review. Curr. Med. and Chem. Anticancer Agents. 5(2):149-160.
Suleiman, MN; Emua, SA; Taiga, A (2008). Effect of aqueous extracts on a spot fungus (Fusarium spp.) isolated from cowpea. Am.-Euras. J. Sust. Agric. 2(3):261-263.

Sweeney, CJ; Mehrotra, S; Sadaria, MR; Kumar, S; Shortle, NH; Roman, Y; Sheridan, C; Campbell, RA; Murray, DJ; Badve, S; Nakshatri, H (2005). The sesquiterpene lactones parthenolide in combination with docetaxel reduces metastasis and improves survival in a xenograft model of breast cancer. Mol. Cancer Therapy. 4(6):1004.

Valenzuela, AH; Smith, J (2002). Cowpea. College of Tropical Agriculture and Human Resources. University of Hawaii at Monica, Honolulu, Hawaii. p 3.

Zaman, MA; Saleh, AKM; Rahman, GMM; Islam, MT (1997). Seed-borne fungi of mustard and their control with indigenous plant extracts. Banglad. J. Plant Pathol.13:25-28.

Ziv, O; Zitter, TA (1992). Effects of bicarbonates and film-forming polymers on cucurbit foliar diseases. Plant Dis. 26(5):513-517. 